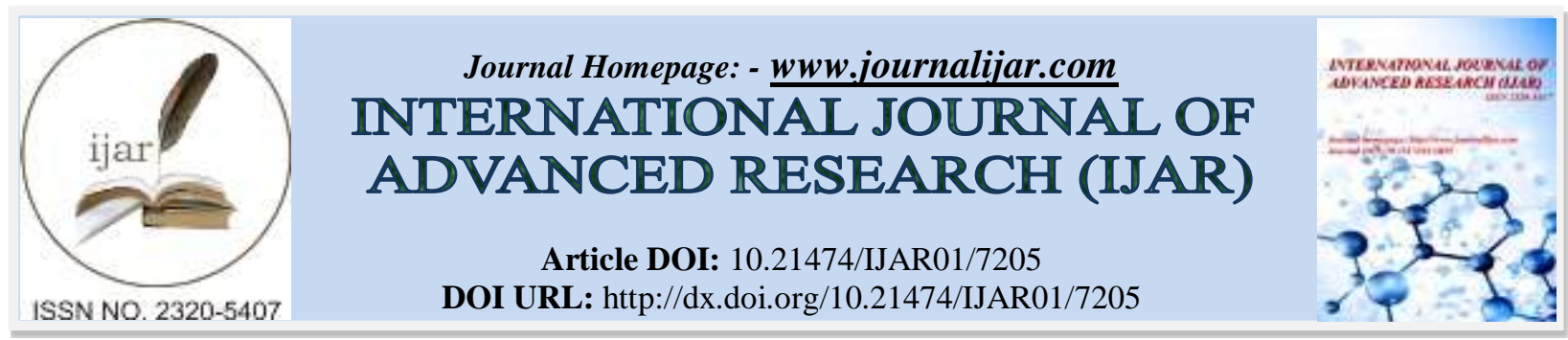

RESEARCH ARTICLE

\title{
HELICOBACTER PYLORI INFECTION IN EGYPTIAN PATIENTS WITH DYSPEPSIA: DIAGNOSTIC, DEMOGRAPHIC, ENDOSCOPIC AND CLINICAL CHARACTERISTICS.
}

\author{
${ }^{*}$ Manal Diab ${ }^{1}$, Ahmed El-Shenawy ${ }^{1}$, Mohamed Shemis ${ }^{2}$, Maged El-Ghannam ${ }^{3}$, Manal El Said ${ }^{1}$, Moustafa \\ Abdelnasser ${ }^{4}$, Mahmoud Abdel-Hady ${ }^{4}$, Effat El-Sherbini ${ }^{1}$ and Mohamed Saber ${ }^{2}$. \\ 1. Department of Microbiology, Theodor Bilharz Research Institute, Giza, Egypt. \\ 2. Department of Biochemistry, Theodor Bilharz Research Institute, Giza, Egypt. \\ 3. Department of Gastroentrology and Hepatology, Theodor Bilharz Research Institute, Giza, Egypt. \\ 4. Medical Microbiology and Immunology Department, Faculty of Medicine Al-Azhar University, Egypt.
}

\section{Manuscript Info}

Manuscript History

Received: 04 April 2018

Final Accepted: 06 May 2018

Published: June 2018

Keywords:-

Helicobacter pylori, PCR, rapid urease test, stool antigen.

\section{Abstract}

Background and Study Aims: Helicobacter pylori (H. pylori) is considered as a public health problem, especially in developing countries. Understanding the epidemiological aspects of $H$. pylori infection is important and helpful in clarifying the consequences and complications of infection. The aim of this study was to assess the prevalence of $H$. pylori infection in dyspeptic patients and to study the demographic, endoscopic and clinical characteristics of $H$. pylori infected patients.

Patients and Methods: A total of 113 adult patients with dyspepsia were enrolled in this study. They underwent upper gastrointestinal endoscopy for obtaining four antratbiopsies, patients were considered to be infected with $H$. pylori when they had positive results of rapid urease and/or H.pylori stool antigen tests and confirmed by detection of H. pylori 16S rRNA gene in the extracted DNA from gastric biopsy specimens by Polymerase Chain Reaction (PCR) assay.

Results: Sixty $(53.1 \%)$ dyspeptic patients (17-76 years old) were confirmed to be infected with $H$. pylori. Age, sex, smoking history and taking spicy food had no significant correlation to the acquisition of $H$. pylori infection. Considering the PCR assay on gastric biopsy specimens as the gold standard, excellent agreement was found with both rapid urease and $H$. pylori stool antigen tests. Rapid urease test (91.7\%) was more sensitive than H. pylori stool antigen test (83.3\%), while both tests have specificity of $100 \%$. Upon endoscopy; gastritis was revealed in $27(45 \%)$ and $10(16.7 \%)$ had peptic ulcer disease (PUD).

Conclusions: H. pylori infection rate in Egyptian patients with dyspepsia was high and gastritis was the most revealed finding upon endoscopy. No risk factors were associated with $H$. pylori infection among the studied adult patients. Combined rapid urease and stool antigen tests can be relied upon for detecting $H$. pylori infection. 


\section{Introduction:-}

H. pylori, a microaerophilic, Gram-negative and spiral bacterium, is colonizing approximately $50 \%$ of the world's population and over $80 \%$ of individuals infected with $H$. pylori are asymptomatic [1]. It plays a significant role in the etiology and pathogenesis of peptic ulcer disease and increases the risk of developing gastric adenocarcinoma and mucosa-associated lymphoid tissue lymphoma [2]. H. pylori is frequently associated with the symptom of dyspepsia which is considered as one of the most common upper gastrointestinal complaints [3].

The prevalence of $H$. pylori infection differs significantly among countries, with higher prevalence (20-90\%) in developing areas compared to developed countries $(10-60 \%)[4,5,6]$. Several studies from Egypt reported that the prevalence of $H$. pylori infection ranged from 60-90\% [7,8,9]. Adult factors associated with prevalence of $H$. pylori are poorly characterized and, in particular, it is unclear whether socioeconomic conditions, lifestyle and household overcrowding in later life are independent predictors of infection $[10,11]$. The geographic variations, in addition to genetic heterogeneity of the host further contribute to the diversity of host responses to particular $\mathrm{H}$. pylori strains and genotypes [11].

Several diagnostic tests for detection of $H$. pylori have been widely used in clinical practice. However, each of these tests has certain disadvantages [12].These diagnostic methods may be classified as invasive, which require endoscopy to obtain biopsies of gastric tissues, and non-invasive. The invasive methods include histological examination, culture, urease test and molecular methods, while the non-invasive methods include urea breath testing, serology and stool antigen testing. There is no single method that can meet, on its own, the criteria for acceptable sensitivity and specificity in identification of the bacterium. In the last few years, more interest has been paid for the non-invasive methods [13].

The aim of this study was to assess the prevalence of $H$. pylori infection in dyspeptic patients and to study the demographic, clinical and endoscopic characteristics of $H$. pylori infected patients. We tried to evaluate the role of combined testing assays for $H$. pylori diagnosis.

\section{Patients and Methods:-}

A total number of 113 adult patients with various symptoms such as dyspepsia (upper abdominal discomfort or pain) vomiting and/or heartburn and undergoing upper gastrointestinal endoscopy at the Endoscopy Unit, Theodor Bilharz Research Institute (TBRI) Hospital from March, 2013 to December, 2015 were enrolled in this study. Patients who had received non-steroidal anti-inflammatory drugs, as well as antibiotics, $\mathrm{H} 2$ receptors antagonists or proton pump inhibitors (PPI) four weeks prior to the study were excluded. All dyspeptic patients who underwent upper endoscopy and fulfilled the inclusion criteria were subjected to complete history (age, sex, residence, complain and habits). Antral Biopsy specimens were obtained from each patient for diagnosis of $H$. pylori infection. A patient was considered to be infected with $\mathrm{H}$. pylori when he had positive results of rapid urease and /or H. pylori stool antigen tests and confirmed by detection of 16S rRNA in gastric biopsy specimens by PCR assay. The study protocol conforms to the ethical guidelines of the 1975 Declaration of Helsinki $\left(6^{\text {th }}\right.$ revision, 2008) as reflected in a priori approval by TBRI institutional review board (FWA00010609) and all patients provided a written informed consent.

\section{Sample Collection}

Gastric biopsies: Upper gastrointestinal endoscopy was performed using an Olympus X Q40 endoscope. Upper endoscopic examination of the esophagus, stomach and duodenum, abnormalities (gastritis, ulceration, erosion and others) were recorded. From each patient, four biopsies were obtained from the antrum and corpus in 2 tubes. One tube was tested for rapid urease test and the other tube was stored in sterile physiological saline in sterile Eppendorf tubes and kept at $-70^{\circ} \mathrm{C}$ until processed as panel for DNA extraction were used directly for PCR assay.

Stool specimens: One stool specimen was taken from each patient to be tested for detecting H. pylori antigen. Stool specimens were collected in sterile plastic cups and kept at $-70^{\circ} \mathrm{C}$ until processed.

Rapid urease liquid test:

H. pylori urease production in gastric biopsy was detected using rapid urease liquid test kit (Bussero, Milan, Italy).

Detection of H. pylori antigen in stool specimens:

H.pylori antigen in stool specimens was detected using Immunospec Corporation Kit (Netherlands). The test utilizes purified anti- $H$. pylori capture antibody to detect $H$. pylori antigen in diluted stool specimens [14]. 
A standard curve was constructed for calculation of $H$. pylori stool antigen results by plotting the optical density on the $\mathrm{y}$-axis against the concentration of the calibrator $\mathrm{ng} / \mathrm{ml}$ values on the $\mathrm{x}$-axis. Negative results: $<15 \mathrm{ng} / \mathrm{ml} \mathrm{while}$ positive results: $>20 \mathrm{ng} / \mathrm{ml}$.

DNA extraction and detection of $H$. pylori $16 S$ rRNA gene by conventional PCR assay:

Genomic DNA was extracted from gastric biopsy specimens using QIAamp DNA min kit (Qiagen, USA) according to manufacturer guidelines. PCR assay was performed in a volume of 50ul with approximately $5 \mu \mathrm{g}$ of extracted DNA, $200 \mu \mathrm{M}$ (each) dNTPs, 25 pmol for each primer (Table 1), $1.5 \mu \mathrm{M}$ Magnesium Chloride and 1unit of Taq polymerase (Gotaq Flexi DNA, M8305, Promega, Inc, USA) in PCR buffer. The reaction was done in PTC-100 ${ }^{\mathrm{TM}}$ thermal cycler (MJ Research, USA), programmed as follows: denaturing at $95^{\circ} \mathrm{C}$ for 5 min, followed by 37 cycles of denaturation at $95^{\circ} \mathrm{C}$ for $1 \mathrm{~min}$, annealing at $60^{\circ} \mathrm{C}$ for $1 \mathrm{~min}$ and extension at $72^{\circ} \mathrm{C}$ for $1 \mathrm{~min}$, and final extension at $72^{\circ} \mathrm{C}$ for 5 minutes. PCR product was separated on $2 \%$ agarose gel with ethidium bromide, and 50bp ladder used as DNA molecular weight standard. In PCR assay, a negative control (lacking DNA) was included. PCR products were analyzed under UV light. Size of expected amplicon was 110bp [15].

Statistical analysis:

Data were described in terms of frequencies (number of cases) and relative frequencies (percentages). P-value < 0.05 was considered as statistically significant. All statistical calculations were done using computer programs Microsoft Excel 2007 (Microsoft Corporation, NY, U.S.A.).

Table 1:- Primer used for PCR analysis of H. pylori 16S rRNA gene

\begin{tabular}{|l|l|c|l|}
\hline Target gene & Primer sequence (5'-3') & Amplicon bp & Reference \\
\hline 16S Rrna & $\begin{array}{l}\text { 5'CTG GAG AGA CTA AGC CCT CC-3' } \\
\text { 5'ATT ACT GAC GCT GAT TGT GC-3' }\end{array}$ & 110 & Chisholm et al[15] \\
\hline
\end{tabular}

\section{Results:-}

Diagnostic performance of different assays used for diagnosis of H. pylori infection:

Regarding results of different assays used for diagnosis of $H$. pylori infection among 113 dyspeptic patients included in the study; for conventional PCR assay, 60 (53.1\%) patients showed positive H. pylori DNA in gastric biopsy specimens, 55(48.6\%) gastric biopsy specimens had positive rapid urease test and $50(44.2 \%)$ patients had positive $H$. pylori stool antigen. The diagnostic performance analysis of different assays on gastric biopsies and stool specimens, considering PCR assay on gastric biopsy specimens as the gold standard, was; 60 (53.1\%) patients were diagnosed to be infected with $H$. pylori by positive results of rapid urease and /or H. pylori stool antigen tests and confirmation by detection of $16 \mathrm{~S}$ rRNA in gastric biopsy specimens. The sensitivity rate of rapid urease test (91.7\%) was higher than that of $H$. pylori stool antigen test (83.3\%) and for specificity rate of both tests was $100 \%$. Excellent agreement was found with rapid urease test and stool antigen test, with Kappa coefficient of 0.912 and 0.824 ; respectively (Figure 1 and Table 2)




Figure (1):- Agarose gel electrophoresis of PCR products of H. pylori $16 S$ rRNA positive gene (110 bp) from gastric biopsy specimens on agarose gel. Lane M: molecular weight marker (ladder 50 bp). Lanes (1-5): Positive cases of H.pylori possessing $16 S$ rRNA gene. Lane $\mathrm{N}$ : negative control

Table 2:- Diagnostic performance of biopsy-based rapid urease and stool antigen tests among the studied $60 H$. pylori infected patients

\begin{tabular}{|c|c|c|c|c|c|c|c|c|}
\hline \multirow{2}{*}{$\begin{array}{l}\text { Test } \\
(n=113)\end{array}$} & \multicolumn{2}{|c|}{$\begin{array}{c}\text { PCR assay on gastric } \\
\text { biopsy }\end{array}$} & \multirow[t]{2}{*}{ Sensitivity } & \multirow[t]{2}{*}{ Specificity } & \multirow[t]{2}{*}{ PPV } & \multirow[t]{2}{*}{ NPV } & \multirow[t]{2}{*}{ Efficacy } & \multirow[t]{2}{*}{$\begin{array}{c}\text { Kappa } \\
\text { value }\end{array}$} \\
\hline & $\begin{array}{c}\text { Positive } \\
(n=60)\end{array}$ & $\begin{array}{l}\text { Negative } \\
(n=53)\end{array}$ & & & & & & \\
\hline \multicolumn{9}{|c|}{ Rapid urease test } \\
\hline Positive $(n=55)$ & $\begin{array}{c}55 \\
(91.7 \%)\end{array}$ & $0(0.0 \%)$ & \multirow[t]{2}{*}{$\begin{array}{c}55 / 60 \\
(91.7 \%)\end{array}$} & \multirow[t]{2}{*}{$\begin{array}{c}53 / 53 \\
(100 \%)\end{array}$} & \multirow[t]{2}{*}{$\begin{array}{c}55 / 55 \\
(100 \%)\end{array}$} & \multirow[t]{2}{*}{$\begin{array}{c}53 / 58 \\
(91.4 \%)\end{array}$} & \multirow[t]{2}{*}{$\begin{array}{l}108 / 113 \\
(95.6 \%)\end{array}$} & \multirow[t]{2}{*}{0.912 米 } \\
\hline $\begin{array}{l}\text { Negative }(n= \\
58)\end{array}$ & $5(8.3 \%)$ & $53(100 \%)$ & & & & & & \\
\hline \multicolumn{9}{|l|}{ Stool antigen test } \\
\hline Positive $(n=50)$ & $\begin{array}{c}50 \\
(83.3 \%) \\
\end{array}$ & $0(0.0 \%)$ & \multirow[t]{2}{*}{$\begin{array}{c}50 / 60 \\
(83.3 \%)\end{array}$} & \multirow[t]{2}{*}{$\begin{array}{c}53 / 53 \\
(100 \%)\end{array}$} & \multirow[t]{2}{*}{$\begin{array}{c}50 / 50 \\
(100 \%)\end{array}$} & \multirow[t]{2}{*}{$\begin{array}{c}53 / 63 \\
(84.1 \%)\end{array}$} & \multirow[t]{2}{*}{$\begin{array}{l}103 / 113 \\
(91.2 \%)\end{array}$} & \multirow[t]{2}{*}{0.824 *** } \\
\hline $\begin{array}{l}\text { Negative }(n= \\
63)\end{array}$ & $\begin{array}{c}10 \\
(16.7 \%)\end{array}$ & $53(100 \%)$ & & & & & & \\
\hline
\end{tabular}

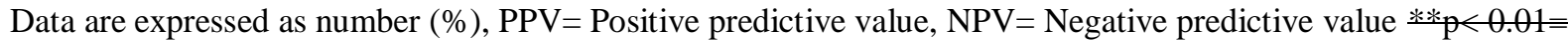
Highly significant

Demographic features of the studied patients:

Among the studied $60 \mathrm{H}$. pylori infected patients, $40(66.7 \%)$ patients were males and $20(33.3 \%)$ were females $(\mathrm{P}$ value $=0.26)$. The patients' ages ranged between 17 and 76 years $(49.93 \pm 14.28$ years $)$, and 85\% $(51 / 60)$ patients were from urban region while $15 \%(9 / 60)$ were from rural region $(\mathrm{P}$ value $=0.97)$. Half of the $H$. pylori infected patients $(31 / 60,51.7 \%)$ were above 51years, $46.7 \%(28 / 60)$ were between 21 and 50 years, while only one patient $(1.7 \%$ ) was below 20 years ( $\mathrm{P}$ value $>0.5)$. H. pylori infection increases with age, and was possibly found more in population above 51 years.

Risk factors associated with H. pylori infected patients:

The risk factors associated with $H$. pylori infection include smoking and eating spicy food (13/60; 21.7\%; each) and both factors were detected in $10 \%(6 / 60)$ of patients ( $\mathrm{P}$ value $>0.5)$.

Table 3:-Risk factors associated with H.pylori infected patients

\begin{tabular}{|l|c|c|}
\hline \multirow{2}{*}{} & \multicolumn{2}{|c|}{ H. pylori Infected Patients (n=60) } \\
\cline { 2 - 3 } Risk factors & No. & 21.7 \\
\hline Smoking history & 13 & 21.7 \\
\hline Eating spicy food & 13 & 10 \\
\hline Smoking history and eating spicy food & 6 & \\
\hline
\end{tabular}

Data are expressed as number $(\%)$

Clinical and Endoscopic Findings of the Studied Patients:

Most of the studied $60 \mathrm{H}$. pylori infected patients presented mainly with dyspepsia 34(56.7\%) followed by vomiting $16(26.7 \%)$ then heartburn 10(16.7\%). Upon upper gastrointestinal endoscopy of the gastroduodenal mucosa $H$. pylori infected patients revealed gastritis (hyperemic mucosa) in $45 \%$, whereas $16.7 \%$ of such patients have peptic ulcer disease. Other endoscopic findings as antral erosion, gastric prolapse, GERD, esophageal varices, esophagitis and hiatus hernia were detected in $31.7 \%$ patients and $6.7 \%$ of patients had apparently normal gastric mucosa (Table 4). 
Table 4:- Clinical and Endoscopic findings among H. pylori infected patients

\begin{tabular}{|l|c|c|}
\hline \multirow{2}{*}{ Clinical findings } & \multicolumn{2}{|c|}{ H. pylori Infected Patients (n=60) } \\
\cline { 2 - 3 } Dyspepsia & No. & \% \\
Vomiting & 34 & 56.7 \\
Heart burn & 16 & 26.7 \\
Endoscopic Findings & 10 & 16.6 \\
\hline Gastritis & & \\
\hline Peptic Ulcer & 27 & 16.0 \\
\hline Apparently Normal Gastric Mucosa & 10 & 6.7 \\
\hline Others (antral erosion, gastric prolapse, GERD, oesophageal & 4 & 31.7 \\
varices, oesophagitis and hiatus hernia) & 19 & \\
\hline
\end{tabular}

Data are expressed as number $(\%)$

\section{Discussion:-}

H. pylori infection prevalence rates vary from country to country and differ greatly among population groups within the same country. It can be due to diverse contributing factors including socioeconomic status, geographical or living conditions and location of each population $[4,5,16]$. In the current study, $53.1 \%$ of the studied patients were H. pylori infected positive by rapid urease test and/or stool antigen test and confirmed by detection of $16 S$ rRNA gene by PCR assay in panel of gastric biopsy specimens. Comparable results H.pylori infection were recorded by Goh [17] from Malaysia (49\%), by Alazmi et al [18] Kuwait (49.7\%) and by Hasosah et al [19] from Saudi Arabia (49.8\%). Previous Egyptian studies recorded higher results; Diab et al [7] detected H. pylori 16SrRNA gene in a rate of 64.3\% in gastric biopsy specimens by PCR assay; Ali and Borei [20] and Abu-Zekry et al [21] recorded $H$ .pylori infection of $62 \%$ and $70 \%$ using $\mathrm{C} 13$-urea breath test and $\mathrm{H}$. pylori antigen detection in stool respectively. A recent Egyptian study by El-Khlousy et al [22] reported that $H$. pylori infection was detected in $62.2 \%$ by histopathology while $75.7 \%$ were positive for $H$. pylori 16S rRNA gene by PCR. Egypt had the highest prevalence of $H$. pylori in the healthy asymptomatic population both in adults and the pediatric age group. Low socioeconomic status, low body weight and height, living in rural areas and lower educational status were risk factors for the acquisition of $H$. pylori in Egyptian studies [23]. In contrast, studies which reflect good hygienic conditions and less crowded environments reported a much lower prevalence from several European countries [16, 24].

In the current study, $85 \%$ of $\mathrm{H}$. pylori infected patients were from urban region where these patients are living in a low-income urban region with low educational level. Similarly, previous studies reported higher prevalence rates of H. pylori infection in low-income urban areas [10]. Jaka et al [24] also reported significantly higher prevalence rates of $H$. pylori infections in rural areas compared to urban areas.

In the present study, although the prevalence of $H$. pylori infection was higher in males, however, no statistically sex difference was found as it has also been found in other studies conducted in developing countries, there were no gender differences in the risk of acquisition of infection [18]. On the contrary Niknam, et al [25], reported predominant $H$. pylori positivity in females.

Age was shown to have an effect on the prevalence of $H$. pylori infection with lower rates in subjects younger than 20 years old [26]. Ford and Axon [27] reported that $H$. pylori infection prevalence increases with age between 7\% and $87 \%$. Among adults, the $H$. pylori infection rate increases with age [24].The current study the prevalence of $H$. pylori infection increases with age; however the differences were not significant. Hu et al [28] reported that the highest prevalence of $\mathrm{H}$. pylori was in 40-49 years age group, they explained that these subjects always tend to dine out which increases the chance of exposure to $H$. pylori infection.

Smoking is a social stigma that is fast growing into an epidemic. It has been elucidated in molecular studies that smoking causes the expression of $\operatorname{cag} A$ gene in the gastric milieu. This gene could play a role in the transformation of an ulcerated gastric lining into a malignant tumor [29]. In the current study, smoking was associated with $H$. pylori infection in $21.7 \%$. Such result was contradictory to Bakka and Salih [26] study and was consistent with previous study by $\mathrm{Hu}$ et al [28] who reported that the use of tobacco had been shown to impair the immune system, therefore contributing to an increased chance of H.pylori infection. 
H. pylori infection could also be related to eating habits [30]. In the current study, eating spicy food, as a risk factor, is associated for $H$. pylori infection. These results were in agreement with Hu et al [29] who reported that spicy food and pickle food are risk factors for $H$. pylori infection. Spicy food and pickle food may decrease the ability of gastric mucosa to prevent $H$. pylori infection and a high intra-gastric salt content may destroy the mucosal barrier, leading to inflammation and damage such as diffuse erosion and degeneration in the stomach.

Dyspepsia is a common gastrointestinal disorder and could present as dysmotility or ulcerative like dyspepsia. It is considered as the most common indication for gastric upper endoscopy [31]. The current study showed that $56.7 \%$ of the H.pylori infected patients were presented with dyspepsia. Such results were lower than those found by Vilaichone et al [32] from Thailand. In the Western World, the prevalence of dyspepsia was ranged between 25 to $50 \%$ [25]. Savarino et al [33] documented that up to $70 \%$ of reflux patients have typical reflux symptoms (i.e. heartburn and/or regurgitation) in the absence of endoscopic visible oesophageal mucosal injuries.

More than $50 \%$ of the world's population is infected with $H$. pylori [27], however, $10 \%$ only will develop peptic ulcer disease and $1 \%-2 \%$ will develop gastric malignancy [34]. The upper gastrointestinal endoscopy of the studied H. pylori infected patients revealed that, the most common findings were gastritis (45\%) followed by peptic ulcer (16.7\%). Our results were in agreement with Ngoyi et al [35] and lower than Rasheed et al [36]. Feliciano et al [37] reported that during upper endoscopy, patient's mucosa was distributed into non-peptic ulcer dyspepsia in 64.7\% and peptic ulcer in $35.3 \%$ of cases. Other endoscopic findings (31.7\%) were observed among the studied $\mathrm{H}$. pylori infected patients. Moschos et al [38] showed that H. pylori eradication may positively influence GERD symptoms. Ngoyi et al [35] had detected hiatal hernia in 1.6\% of the examined cases. Another study from Egypt by Safwat et al [39] showed that there is significant association between H. pylori infection and the occurrence and the severity of portal hypertensive gastropathy (which may be associated with esophageal varices) in patients with HCV-related liver cirrhosis, thus, eradication of H.pylori may be beneficial to improve portal hypertensive gastropathy.

Of the several available diagnostic tests for detection of $H$. pylori infection, the choice depends on the sensitivity, specificity, reproducibility, availability cost, and rapidity of the results. There is a need for a reference method to be used as "gold standard" to detect patients truly infected. Unfortunately, none of the currently used methods is able to further this criterion [40]. Nowadays, studies show that the PCR assay may be slightly superior to other diagnostic methods for detection of $H$. pylori from different clinical samples and to verify the bacterium eradication after treatment. The need for a limited amount of bacteria enables PCR to recognize infection when other tests are negative due to low bacterial density [41].

In the current study, $53.1 \%$ of the studied patients were $H$. pylori positive by rapid urease test and/or stool antigen test and confirmed by detection of $16 \mathrm{~S} r R N A$ gene by PCR assay in panel of gastric biopsy specimens. We tried to combine the results of two techniques, and compare with results of each method being evaluated. Using PCR assay as gold standard, the diagnostic performance of the studied assays revealed that both invasive biopsy-based rapid urease test and $\mathrm{H}$. pylori stool antigen test as a non-invasive method had excellent agreement.

Concerning first-choice diagnostic tests for $\mathrm{H}$. pylori, the American College of Gastroenterology recommended biopsy-based tests. Among these, rapid urease test is the most popular test in clinical practice but has high variable number of false-negative results according to a meta-analysis [42]. False positive results can occur if other urease containing organisms are present in sufficient quantity. The sensitivity of urease test is also affected by the amount of bacteria in the biopsy [43]. In the current study, sensitivity and specificity rates of rapid urease test was $91.7 \%$ and $100 \%$ respectively detection of $H$. pylori infection from the biopsy site and the pooled 3 biopsies sites helps to detect even more patients with $H$. pylori infection. Our results were comparable with Parihar et al [44] and higher than Allahverdiyev et al [45]. Nevoa et al [46] found that the rate in the detection of H. pylori by the molecular method was significantly higher when compared to the rapid urease test.

Several non-invasive tests have been developed to diagnose H. pylori. H.pylori stool antigen has been detected successfully, using purified antibodies by immunoassay. It is a reliable method to diagnose an active infection and to evaluate the eradication of H.pylori infection. However, if the concentration of H.pylori antigen becomes low, false negativity may also be reported [47]. In the current study $H$. pylori stool antigen test showed a sensitivity rate of $83.3 \%$ and specificity rate of $100 \%$. Higher sensitivity rates $(92.4 \%)$ and a specificity rate of $100 \%$ was reported by Okuda et al [48]. Comparable results were recorded by Me'graud et al [49]. A lower sensitivity rate and a comparable specificity rate were revealed by Korkmaz et al [50]. Saha et al [51] found that H.pylori 
stool antigen test was superior to upper gastrointestinal endoscopy for detection of H.pylori infection and recommended for initial testing for H.pylori infection in dyspeptic patients before initiating treatment and before carrying out any invasive procedure such as endoscopy.

In conclusion, $H$. pylori infection rate in Egyptian patients with dyspepsia was high and gastritis was the most revealed finding upon endoscopy. No risk factors were associated with $H$. pylori infection among the studied adult patients. Combined rapid urease and stool antigen tests can be relied upon for detecting H. pylori infection. Noninvasive method could be used for $H$. pylori re-testing when invasive tests are negative or could not be done.

\section{Conflict of interest:-}

We have no conflict of interest to declare.

\section{Acknowledgement:-}

I would like to thank professoer Tarek Diab, parasitology lab., TBRI, for his assistance for the statistical analysis.this work was supported by Theodor Bilharz Research Institute (TBRI) as a part of an ongoning internal project No.93T.

\section{References:-}

1. Treiber G, Malfertheiner P, Klotz U. Treatment and dosing of Helicobacter pylori infection: when pharmacology meets clinic. Expert Opin Pharmacother 2007; 8(3):329-50.

2. Dudley J, Wieczorek T, Selig M, Cheung H, Shen J , Odze R, et al. Clinicopathological characteristics of invasive gastric Helicobacter pylori. Hum Pathol 2017; 61: 19-25.

3. Pittman ME, Khararjian A, Wood LD, Montgomery EA, Voltaggio L. Prospective identification of Helicobacter pylori in routine gastric biopsies without reflex ancillary stains is cost-efficient for our health care system. Hum Pathol 2016; 58: 90-96.

4. Khalifa MM, Sharaf RR, Aziz RK. Helicobacter pylori: a poor man's gut pathogen?. Gut Pathog 2010; 2:212.

5. Maleki P, LatifiNavid S, Zahri S. Allelic Variation of Helicobacter pylori babA and cagA Genes and their association with clinical consequences. Govaresh 2013; 17:203-212.

6. Miftahussurur M, Nusi IA, Akil F, Syam AF, Wibawa IDN, Rezkitha YAA, et al. Gastric mucosal status in populations with a low prevalence of Helicobacter pylori in Indonesia. PLoS One 2017; 2; 12(5):e0176203.

7. Diab M, Saad El-Dine S, Aboul-Fadl L, Omran Z, Shemis M, El-Gannam M, et al . H. pylori cag pathogenicity island genes among dyspeptic patients with chronic gastritis. EJMM 2009; 18: 43-53.

8. Mohamed SM, El Touny MAEA, Ahmed OA, Hafez HM, Mahmoud IS. Prevalence of Helicobacter pylori among health care workers in endoscopy units. J Amer Scien 2013; 9:192-197.

9. El-Khlousy M, Rahman EA, Mostafa S, Bassam A, Elgawad HA, Elnasr MS, et al. Study of the clinical relevance of Helicobacter pylori virulence genes to gastric diseases among Egyptian patients. Arab J Gastroenterol 2016;17(2):90-94.

10. Rodrigues MN, Queiroz DMM, Rodrigues RT, Rocha AMC, Neto MBB, Braga LLBC. Helicobacter pylori infection in adults from a poor urban community in northeastern brazil: demographic, lifestyle and environmental factors. Braz J Infect Dis 2005; 9(5):405-410.

11. Thevakumar K, Chandren JR, Perez-Perez GI, Chua EG, Teh LK, Salleh MZ, et al. Assessment of risk and sero-prevalence of Helicobacter pylori colonization among remote Orang Asli tribes in Peninsula Malaysia. PLoS One. 2016 Jul 21;11(7):e0159830.

12. Qi Q, Guo C, Ji R, Li Z, Zuo X, Li Y. Diagnostic Performance of Magnifying Endoscopy for Helicobacter pylori Infection: A Meta-Analysis. PLoS One 2016; 11(12): e0168201.

13. Ibrahim EA-S, Moustafa M A-M, Monis W. Comparison between phenol red chromo-endoscopy and a stool rapid immunoassay for the diagnosis of Helicobacter pylori in patients with gastritis. J Microsc Ultrastruct 2015; 3:175-180.

14. Cutler AF. Testing for H pylori in clinical practice. Am J Med 1996; 100:35-41.

15. Chisholm SA, Owen RJ , Teare EL, Saverymuttu S. PCR-based diagnosis of helicobacter pylori infection and real-time determination of clarithromycin resistance directly from human gastric biopsy samples. J Clin Microbiol 2001; 39(4): 1217-1220.doi: 10.1128/ JCM.39.4.1217-1220.2001

16. Awuku YA, Simpong DL, Alhassan IK, Tuoyire DA, Afaa $\quad$ T, Adu P. Prevalence of Helicobacter pylori infection among children living in a rural setting in Sub-Saharan Africa. BMC Public Health 2017; 17(1):360. doi: 10.1186/s12889-017-4274-z. 
17. Goh KL. Prevalence of and risk factors for $H$. pylori infection in a multi-racial dyspeptic Malaysian population undergoing endoscopy. J Gastroenterol Hepatol 1997; 12:29-35.

18. Alazmi WM, Siddique I, Alateeqi N, Al-Nakib B. Prevalence of $H$. pylori infection among new outpatients with dyspepsia in Kuwait. BMC Gastroenterol 2010; 10:14.

19. Hasosah M, Satti M, Shehzad A, Alsahafi A, Sukkar G, Alzaben A, et al. Prevalence and risk factors of H.pylori infection in Saudi Children: A three-year prospective controlled study. Helicobacter 2015; 20:56-63.

20. Ali AS, Borei MB. H. pylori and Egyptian infantile colic. J Egypt Soc Parasitol 2013; 43:327-332.

21. Abu-Zekry MA, Hashem M, Ali AA, Mohamed IS. Frequency of H.pylori infection among Egyptian children presenting with gastrointestinal manifestations. J Egypt Public Health Assoc 2013; 88:74-78.

22. Mohammad MA, Hussein L, Coward A, Jackson SJ. Prevalence of Helicobacter pylori infection among Egyptian children: Impact of social background and effect on growth. Public Health Nutr 2008; 11: 230-236 [PMID: 17666124]

23. Hooi JKY, Lai WY, Ng WK, Suen MMY, Underwood FE, Tanyingoh D, et al. Global prevalence of Helicobacter pylori Infection: Systematic review and meta-analysis. Gastroenterology 2017; 26. pii: S00165085(17) 35531-2. doi: 10.1053/j.gastro. 2017.04. 022. [Epub ahead of print]

24. Jaka H, Mushi MF, Mirambo MM, Wilson L, Seni J, Mtebe M, et al. Sero-prevalence and associated factors of Helicobacter pylori infection among adult patients with dyspepsia attending the gastroenterology unit in a tertiary hospital in Mwanza, Tanzania. Afr Health Sci 2016; 16(3):684-689.

25. Niknam R, Seddigh M, Fattahi MR, Dehghanian A, Mahmoudi L. Prevalence of H.pylori in patients with dyspepsia. Jundishapur J Microbiol 2014; 10:e12676.

26. Bakka AS, Salih BA. Prevalence of $H$. pylori infection in asymptomatic subjects in Libya. Diagn Microbiol Infect Dis 2002; 43:265-268.

27. Ford AC, Axon AT. Epidemiology of Helicobacter pylori infection and public health implications. Helicobacter 2010; 15:1-6.

28. Hu D, Shao J, Wang L, Zheng H, Xu Y, Song G et al. Prevalence and risk factors of H. pylori infection in Chinese maritime workers. Ann Hum Biol 2013; 40:472-476.

29. Ghosh P, Kandhare AD, Raygude KS, Gauba D, Gosavi TP, Bodhankar SL. Cigarette smoking and $H$. pylori infection: A meta-analysis of literature. Der Pharmacia Lettre 2012; 4:128-134.

30. Miyazaki M, Une H, Aoyama H. Helicobacter pylori infection: Relationship between seroprevalence and dietary preference in a rural area. Acta Med Okayama 2002; 54:39-44

31. Olokoba AB, Gashau W, Bwala S, Adamu A, Salawu FK. Helicobacter pylori infection in Nigerians with dyspepsia. Ghana Med J. 2013; 47:79-81.

32. Vilaichone RK, Panarat W, Aekpongpaisit S, Mahachai V. Clinical characteristics and H.pylori status of gastric cancer in Thailand. Asian Pac J Cancer 2014; 20:9005-9008.

33. Savarino E, Pohl D, Zentilin P, Dulbecco P, Sammito G, Sconfienza L, et al. Functional heartburn has more in common with functional dyspepsia than with non-erosive reflux disease. Gut 2009; 58: 1185-1191.

34. Selgrad M, Bornschein J, Rokkas T, Malfertheiner P. Clinical aspects of gastric cancer and Helicobacter pylori - screening, prevention and treatment. Helicobacter 2010; 15 (1): 40-45.

35. Ngoyi O, Nina E, Atipo Ibara BI, Moyen R, Apendi A, Clausina P et al. Molecular Detection of Helicobacter pylori and its antimicrobial resistance in Brazzaville, Congo. Helicobacter 2015; 20:316-320.

36. Rasheed F, Campbell BJ, Alfizah H, Varro A, Zahra R, Yamaoka Y et al. Analysis of clinical isolates of $H$. pylori in Pakistan reveals high degrees of pathogenicity and high frequencies of antibiotic resistance. Helicobacter 2014; 19:387-399.

37. Feliciano O, Gutierrez O, Valdés L, Fragoso T, Calderin AM, Valdes AE et al. Prevalence of Helicobacter pylori vacA, cagA, and iceA Genotypes in Cuban Patients with Upper Gastrointestinal Diseases. Biomed Res Int 2015; 2015:753710. doi: 10.1155/2015/753710. Epub 2015 Apr 6.

38. Moschos JM, Kouklakis G, Vradelis S, Zezos P, Pitiakoudis M, Chatzopoulos D et al. Two distinct etiologies of gastric cardia adenocarcinoma: interactions among $\mathrm{pH}$, Helicobacter pylori, and bile acids. Front Microbiol 2015; 6: 402.

39. Safwat E, Hussein HA, Hakim SA. Helicobacter pylori in Egyptian patients with HCV-related liver cirrhosis and portal hypertensive gastropathy: Prevalence and relation to disease severity. Life Science Journal 2015 ; 12(3):168-173.

40. Patel SK, Pratap CB, Jain AK, Gulati AK, Nath G . Diagnosis of H.pylori: What should be the gold standard? W J Gastroenterol 2014; 20:12847. 
41. Saez J, Belda S, Santibáñez M, Rodríguez JC, Sola-Vera J, Galiana A et al. Real-time PCR for diagnosing Helicobacter pylori infection in patients with upper gastrointestinal bleeding: comparison with other classical diagnostic methods. J Clin Microbiol 2012; 50: 3233-3237.

42. Quach DT, Luu MN, Hiyama T, To T-HT, Bui QN, Tran TA, et al. Early diagnosis of Helicobacter pylori infection in Vietnamese patients with acute peptic ulcer bleeding: A prospective study. Gastroenterol Res Pract 2017; 2017: 3845067.

43. Lonsdale W , Maurya DK, Wajrak M , Tayc CY, Marshallc BJ, Alameha K . Rapid measurement of urease activity using a potentiometric $\mathrm{RuO} 2 \mathrm{pH}$ sensor for detection of Helicobacter pylori. Sensors and Actuators B: Chemical 2017; 242:1305-1308.

44. Parihar V, Holleran G, Hall B, Brennan D, Crotty P, McNamara D. A combined antral and corpus rapid urease testing protocol can increase diagnostic accuracy despite a low prevalence of Helicobacter pylori infection in patients undergoing routine gastroscopy. United European Gastroenterol J 2015; 0:1-5.

45. Allahverdiyev AM, Bagirova M, Caliskan R, Tokman HB, Aliyeva H, Unal G, et al. Isolation and diagnosis of H. pylori by a new method: Microcapillary culture. World J Gastroenterol 2015; $21: 2622$.

46. Nevoa JC, Rodrigues RL, Menezes GL, Lopes AR, Nascimento HF, Santiago SB, et al. Molecular technique for detection and identification of Helicobacter pylori in clinical specimens: a comparison with the classical diagnostic method. J Bras Patol Med Lab 2017; 53(1): 13-19.

47. Perri F, Manes G, Neri M, Vaira D, Nardone G . Helicobacter pylori antigen stool test and 13C-urea breathe test in patients after eradication treatments. Am J Gastroenterol 2002; 97:2756-2762.

48. Okuda M, Osaki T, Kikuchi S, Ueda J, Lin Y, Yonezawa H, et al. Evaluation of a stool antigen test using a $\mathrm{mAb}$ for native catalase for diagnosis of Helicobacter pylori infection in children and adults. J Med Microbiol 2014; 63: 1621-1625.

49. Me'graud F, Bessède E, Lehours P . Diagnosis of H.pylori infection. Helicobacter 2014; 19: 6-10.

50. Korkmaz H, Findik D, Ugurluoglu C, Terzi Y. Reliability of stool antigen tests: Investigation of the diagnostic value of a new immunochromatographic Helicobacter pylori approach in dyspeptic patients. Asian Pacific JCP 2015; 16: 657.

51. Saha R, Roy P, Das S, Kaur N, Kumari A, Kaur IR. Application of a stool antigen test to evaluate the burden of Helicobacter pylori infection in dyspepsia patients. Indian J Pathol Microbiol 2016;59(1):66-68. 